\title{
MODERN PSYCHOLOGICAL AND PEDAGOGICAL TECHNOLOGIES FOR THE DEVELOPMENT OF STUDENTS' CREATIVITY
}

\section{Vynohradova V. Ye.}

\section{INTRODUCTION}

In modern conditions of development of the state, the issue of the development of creativity of the Ukrainian citizens becomes topical. Not only the development of IT technologies, but also creative industries coming to the fore. Creative activity has a social character; therefore, scientists from various fields are engaged in its problems. Accordingly, the problem of creativity, training and education of a creative person, stimulation of creative work is important in the state policy.

In psychological science, an important place is occupied by the question of the formation and development of a creative personality. Undoubtedly, it is important to pay attention to the conditions of his or her formation and development during training. In particular, in the student period, during professional self-determination and selfdevelopment, the technologies of development of creative thinking matter. In this regard, the development of a creative personality is really of great importance both for the state and for the self-realization of a particular person. After all, scientific and technical progress is increasingly putting forward new socially significant benchmarks in the system of higher education and dictates new requirements for the graduates of higher educational establishments, their professional and personal qualities. The hopes for progressive changes in society, which are simply impossible without the full development of a creative personality, are namely laid on the student youth.

The relevance of the study is conditioned by the need for theoretical generalization of modern pedagogical approaches, significant factors affecting the development of students' creative thinking. There is an urgent need to stimulate the development of creative abilities, flexibility, speed of thinking based on the use of psychological and pedagogical technologies that provide students with independent activity in the educational process and systematic educational work in a creatively developing environment. 
An important contribution to the study of this problem made the scientific works of such leading researchers in this field as E. Torrens, E. E. Tunic, J. Gilford, A. M. Matyushkin, V. O. Molyako, V. I. Barko, Ye. L. Gergel, I. M. Bila, O. I. Bedlinskyi, V. M. Druzhynin, Ye. Sokolov, D. Kolyesov, O. I. Kulchytska, N. S. Leites, R. O. Semenova, B. M. Teplov and others. In the context of fundamentalism and humanitarization, which are the main strategic directions for the development of a higher education institution, the ways to improve vocational training are being defined, in particular, the training of a specialist who is able to make effective decisions based on creative thinking, who combines high professionalism with the socio-psychological qualities of a humanist. For the development of students' creative giftedness there is a need to create favourable social and psychological conditions, since the creative potential can be simply unnoticed or blocked, as a result of which it can be realized at an insufficient level or cannot be used at all.

\section{Theoretical analysis \\ of students' creative thinking development}

Today, the question of the formation and development of the student's personality has become one of the central issues in Ukrainian psychological and educational science. The learning process should ensure that students develop new competencies, knowledge and skills that they need for professional growth. One of the competencies of a modern specialist is creativity.

In creative work both social and personal factors, in particular the psychological qualities of a person, his or her character, willpower, ingenuity, passion, experience, intelligence, intuition, imagination, and so on, take on special significance. An important condition for creativity is the perception of new ideas, the ability to find and raise problems, the independence of behaviour and judgment and at the same time the ability to give in and abandon their previous thoughts, criticality, courage, and tolerance. Purposefulness, perseverance, the ability to ensure the regularity and rhythm of mental work are usually considered to be an important subjective condition for creativity.

The resulting quality of creative thought does not depend only on consciousness, but also on unconscious ideas, impulsive guesses, which perform the function of impulse regarding valuable associations. These factors of creativity give rise to a variety of theoretical ideas about the creative process. 
Such Ukrainian scientists as V. Molyako, A. Muzyka, T. Ravlyuk, V. Bondarovskaya, I.Bila, T. Gorobets-Chmut, M. Smulson and others have reached a significant level in the study of creative thinking.

V. Molyako, revealing the essence of creativity from the standpoint of psychology, notes that "by creativity they understand the process of

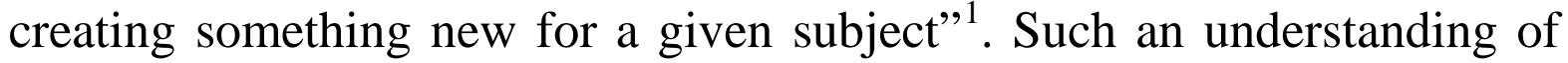
creativity indicates the possibility of finding mechanisms for the development of creative activity as early as in childhood. According to scientists, inventions are one of such mechanisms. In O. Muzyka's invention-strategic model of development of a creatively gifted personality the concept of invention (from the Latin word inventio fiction) is reflected as a natural way of developing creativity. Inventions are considered as spontaneous deviations in the course of activity arising in the process of imitation. Awareness and the use of inventions for the purpose of obtaining a creative result is one of the mechanisms for the spontaneous development of creativity and creative abilities.

Creativity itself is always connected with the creation of something original, unique, individual. The act of creativity, in contrast to actions based on the use of already known techniques and rules that lead to predetermined results, always means finding a completely independent way to achieve the goal. Creativity includes a moment of unpredictability, uncertainty; it is filled with fantasy, intuition, freshness of novelty. The ability for unexpected decisions and for an unusually deep comprehension of reality sharpens in a personality. This very particular stage of inspiration of ordinary professional receptions and rules forms readiness for unexpected turns, which are manifested in the ability to act in completely unpredictable circumstances. A special dynamism of all personality's traits that can be realized in a particular creative act becomes the inner hankering for creativity.

The student period is an important stage in the formation and development of an individual as a whole. It is also important in the development of a person's creative thinking. The peculiarities of manifestation of creativity in the student period are quite contradictory. During this period, the student solves mental problems relatively easily, quickly and efficiently. He or she is able to abstract from concrete quite easily, from visual material and to reflect in verbal terms. On the basis of the general data, he or she builds hypotheses, checks or rejects them when

1 Здібності, творчість, обдарованість: теорія, методика, результати досліджень: Колективна монографія / За ред. В. Моляко, О. Музики. - Житомир: Рута, 2006. - 320 с. 
solving mental problems. Facing the need to solve a problem that is new, in most cases the student seeks to use different approaches to its solution, seeking to find the most effective one. A student's thinking is at the level of formal operations and hypothetical reasoning. The thinking of this age group is abstract and systemic, it is reflexive, and students are able to understand the processes of their own thinking, mental, speech and mnemic strategies. Students are able to manifest flexibility, plasticity; they are ready for changes and discoveries, for cooperation. The thinking of this age category is distinguished by flexible transitions in the relationships of the figurative, logical, and operative components.

One of the main characteristics of thinking at this stage of the development is the complex nature of mental operations with a high level of integration of various types of thinking. For example, the results of theoretical thinking are verified by practice, under the influence of which the enrichment of theoretical thinking takes place too. At the same time, practical thinking associated with the situation which is directly perceived, is repelled from the concepts of theoretical thinking.

In parallel with the development of thinking, imagination and attention develop, which are favourable factors for the manifestation of creativity too ${ }^{2}$. The student forms his or her personal opinion, position selected by himself or herself. The student has great creative potential that needs to be developed and which cannot be allowed to die out. For thinking, as a higher mental process, the activity in which a person is engaged is really essential. Classes of creative activity are a prerequisite for the formation of students' skills and abilities to solve problem tasks set before them.

Creativity itself is always related to the creation of something original, unique, individual. The act of creativity, in contrast to actions based on the use of already known methods and rules that lead to predetermined results, always consists in searching for a completely independent path to achieving a goal. Creativity includes a moment of unpredictability, uncertainty; it is filled with fantasy, intuition, freshness of novelty. The ability for unexpected decisions, an unusually deep comprehension of reality is sharpened in a personality. This very particular stage of inspiration of the ordinary professional receptions and rules forms readiness for unexpected turns, which are manifested in the ability to act in completely unpredictable circumstances. A special

${ }^{2}$ Кривопишина О. А. Психологія творчості [Текст] / О. А. Кривопишина. - Суми: СумДУ, 2009. $-81 \mathrm{c}$. 
dynamism of all personality's traits that can be realized in a particular creative act becomes the inner hankering for creativity.

It is possible to speak about professional development only in cases when a person is aware of participation and responsibility for everything that happens to him or her, and tries to actively promote or resist external circumstances, plan and set goals for professional activity, changing oneself in order to achieve them.

Malimon V.I. identifies five areas of formation and development of a student as a creative personality ${ }^{3}$.

1. The development of a student's personality with a life orientation "to be," not "to have."

1. The mindset "to be", according to E. Fromm, means "to be renewed, to grow, to be poured out, to love, to break free from the walls of one's isolated "Self", to have deep interest, to go to something sensually, to give away" 4 . So, the educational process should be aimed at overcoming egocentrism, at updating the structure and content of education.

2. Comprehensive development of a student's personality.

The system of higher education should prepare a universal person, whose goal and purpose should be "integral knowledge" and "integral world”, about which our compatriot V.I. Vernadskyi wrote at the beginning of the twentieth century. Therefore, a need for a "holistic integral study of the individuality arises," notes V. Merlin. The solution of any practical problem in relation to a person is the most complete and accurate only when the whole variety of conditions is taken into account, determining the activity of a person and, consequently, the diversity of those individual peculiarities of a different hierarchical level on which this activity depends ${ }^{5}$.

3. The priority of the spiritual and moral development of the student's personality.

The process of developing a student's personality should be based on the world's best cultural achievements of mankind, self-awareness as part of this culture and the formation of one's own cultural world.

4. Free development of the student's personality.

The student must cultivate his or her intellect and rational forces. As the French educator and thinker N. Lebel rightly notes on this, "you need to slowly but persistently bring students through thinking, manual work,

${ }^{3}$ Малімон В. І. Перспективи формування та розвитку студента як творчої особистості / В. І. Малімон // Вища освіта України. - 2006. - № 1. - С. 142-145., с. 144.

${ }^{4}$ Фромм Э. Иметь или быть. 2 изд., доп. - М.: Прогресс, 1990. - 180 с., с. 94.

${ }^{5}$ Там само. - C. $142-145$, с. 118. 
knowledge acquisition, to scientific research, to choosing the proper behaviours and self-care, to teach to see, listen, think, reflect, have a clue about the hierarchy of the meanings of eternal values"6. The student has the right to choose in the learning process and teachers should tke this into account.

5. Formation of noospheric thinking in students in the process of studying at a higher educational establishment.

Humanitarian training should be focused on the formation of a specialist with a broad outlook, knowledge of history, culture, philosophy and the foundations of the state formation, with developed feelings of civic consciousness and responsibility, formed by moral and ethical values and principles and norms ${ }^{7}$.

For the formation of creativity as a personal, and not only behavioural properties, a specially organized environment is required. The so-called "local" methodologies of developing creativity (for example, performing non-standard tasks) are certainly useful. But as a result of their use, students often only learn some new ways of doing the task and subsequently reproduce learned actions (for example, teams in intellectual competitions compete in a special way). In such cases, creativity manifests itself in response to external influences, in certain circumstances, and not as a result of the subject's personal needs. That is why for the formation of creativity as a personal trait, a special environment providing a diverse systemic effect on a student, is required.

Psychological and pedagogical conditions that influence the formation of the experience of creative thinking can be divided into two groups: objective (situational) and subjective (personal). Subjective conditions are stable traits of a person's character, capable of influencing the states caused by a particular situation. Objective conditions include such environmental conditions, such organization of the educational process where students' initiative of is not suppressed, confidence in their strengths and capacities is formed in them, independence is stimulated and imagination is developed. Subjective (personal) conditions are a set of personality characteristics, influencing which (with the help of pedagogical techniques, methods, and means), experience of creative thinking of future specialists is formed. Objective (situa-

\footnotetext{
${ }^{6}$ Дзвінчук Д. Формування позитивної мотивації студентів при вивченні гуманітарних дисциплін в технічному університеті // Проблеми викладання гуманітарних дисциплін у технічних навчальних закладах. Матеріали регіональної науково-методичної конференції. - Івано-Франківськ, 2001. - С. 5-8, c. 113.

${ }^{7}$ Там само.
} 
tional) conditions provide the possibility of a purposeful pedagogical (formative) action, and also orient him or her in accordance with the goals set. This combination includes the following components ${ }^{8}$ :

a) Personality and behaviour of a pedagogue. The pedagogue acts as the main character of the technological process, he organizes it, provides concrete practical interaction with students, including them in the generally accepted system of values, strengthens the students' motivational support, activates their creative potential. The students' creative activity increases when the teacher shows his or her own creativity. The pedagogue should be able to create the conditions and carry out actions in order to cause the necessary and planned changes in the students' consciousness, thinking, behaviour and relationships; the teacher's functions include a real assessment of students' activities, because the rewards and punishments themselves form and reinforce the habit; the teacher should be the model, the example of a creative person, to whom students may and want to orient in their activities;

б) Material and technical base. Knowledge forms the basis of any professionally significant qualities, any abilities and skills. Mastering the necessary knowledge by students is one of the most important tasks of the educational process. To obtain a sufficient amount of knowledge, students should not only have an interest in the educational process and the skills of independent teaching and research activities, but also have the appropriate means. These include literary funds, computer software, the ability to use information bases on the Internet, and access to the cultural values of society;

в) The organization of the educational process. The organization of the educational process aimed at shaping the experience of professional and creative thinking should be characterized by problematicity. The necessity to resolve the contradiction between the presence of a problem and the impossibility of solving it under certain conditions induces the student to have a need for additional information and, therefore, affects the motivational sphere of his or her personality, forming cognitive needs.

So, the process of formation of creative thinking experience in students consists in purposeful interaction, co-creation of a pedagogue

\footnotetext{
${ }^{8}$ Иванова И. П. Развитие творческого мышления студентов в условиях проблемнодеятельностного обучения / И. П. Иванова. - Ставрополь, 2002.
} 
and a student in adequate specially organized conditions with the use of necessary mechanisms, forms and methods of organizing classes.

It should be noted that the development of creative abilities requires a long influence and should be the subject of attention of teachers from the first days of students' training. In our opinion, it is necessary to pay attention to rearing of hankering for creativity at all the stages of training.

Based on the abovementioned, as well as taking into account the requirements of the labour market, it can be concluded that there is an objective need for training polyfunctional specialists.

\section{The influence of the educational process peculiarities on the development of students' creativity}

In modern conditions, there is an increasing social demand for a specialist who is able to orientate oneself in a modern multicultural space, make reasonable management decisions, take care of other people subjects of communication, and the like. However, at this stage of development of the society, in the unstable conditions formed in the educational system, many of its parties, both pedagogues and students, experience crisis periods in training. Unfortunately, today obsolete approaches to training may be observed, and also very often prospective students make an unconscious or random choice of a speciality, which affects their learning motivation and the quality of higher education in general. We present some problems that hinder the development of creative abilities and the formation of students' creativity.

1. Reducing learning motivation in terms of a formal approach to the presentation of educational material. Unfortunately, students often come after school without any desire to study. They are accustomed to a consumer position to perceive information and not to be responsible for their knowledge. Our research shows that less than $10 \%$ of students conduct self-checking of the homework done. Therefore, they completely rely on the teacher and his assessment. Thus, it is necessary to form students' personal responsibility for learning.

2. The absence of students' vision of a further perspective in the application of purely theoretical knowledge, which is often out of tune with the necessary requirements for employment.

3. Obtaining a formal education due to the pressure of relatives, families, "for show", "it is fashionable to have a higher education", etc.

4. The deficit of practice in the learning space. In fact, many students say that practical classes are held in artificial (classroom) conditions, without immersing directly into the sphere of their future profession. 
5. The presence of stereotypical perception by many teachers as for the students (expert, prevailing position), the fear of appearing incompetent in the manifestation of a democratic approach to teaching material, the fear of losing the usual framework for conducting classes, complications of the knowledge transmission ways, pressure from management. The emphasis on rigid subordinate positions of "teacherstudent" as "senior-junior", which leads to subjective distancing of both sides of training and the emergence of ostentatious obedience or resistance to the entire educational process.

6. The personal barriers of the students themselves: "it's not allowed, it's not accepted" to ask teachers "superfluous" questions, to communicate in an "equal" position (even in the case of age-related, social, and intellectual equality), risking to provoke their condemnation, disapproval of their peers, classmates.

7. The absence of well-coordinated work of public services and educational institutions that are responsible for the objective presentation of information about the professions necessary for the country and the demand for jobs caused by the desire to maintain themselves in the educational market, not to lose a source of income, and the like.

8. Low material base of the majority of higher educational establishments in Ukraine, which leads to limited access for students to acquiring practical skills during laboratory classes.

Therefore, it should be noted that in the complexities of the educational process of training specialists, not only the immediate interacting parties of the teacher and the student take part, but also other equally important components of this process: government structures, higher educational establishment management, students' families and teachers, close social environment, reference groups and many others, that is, a holistic educational ecosystem.

Thus, by all the listed features, the current state of the system of professional training of future specialists does not always contribute to the development of creative abilities and the formation of students' creativity. However, today most professions often require taking non-standard and fast decisions, therefore a person who graduates must necessarily develop his or her creative abilities. It should be noted that for the leader of any level, creativity is a necessary component of the profession.

A department is the main structural educational and scientific subdivision of a higher educational establishment. The quality of the educational process and the ability of future specialists to become competitive in the labor market depends on the effectiveness of its work. 
In our opinion, it is necessary to determine the main focus areas of the department, which influence the formation of the students' creativity.

1 . The graduating department prepares the curriculum, according to which the educational process is carried out. Today, taking into account new standards in which such competencies as creativity in solving issues are outlined, it enables higher educational establishments to select and design a pedagogical process according to any model, including the author's one. That is, the department, based on a specific scientific school, can determine the direction of the specialists' development, choosing disciplines and forms of training classes.

2. Each teacher prepares training work programs. They must meet general requirements, such as: modernity of knowledge, the connection of theory with practice, they must contain practical exercises (tasks, problems), a student's independent work (result), a list of references, links to the Internet editions. These programs are necessary not only for teachers, but also for students for their independent work.

3. Also important is the choice of teaching methods. It is proved that passive teaching methods (a lecture, preparation of reports) have a low level of acquisition of knowledge. But active learning methods such as discussion, debate, case study, business ones, role-playing, simulation games, brainstorming, participatory methods, a round table, working on joint projects have a high level of knowledge learning. So, teachers must shift from passive forms of education to active ones.

4. I would also like to note the joint activities of teachers of a graduating department. In our opinion, only uniform requirements, a unified position of all teachers can bring the best results in the training of young professionals. That is, a peculiarity of the department's staff is that the individual efforts of teachers will not bring the desired success if they are not coordinated with the actions of others. So, one of the main tasks of the head of the department is to create a team of like-minded people.

It should also be noted that the general concept of training specialists should have a humanistic focus, fundamental, scientific, general cultural, practical content of a specialist's training, taking into account his individual characteristics and potentials. It is necessary to create conditions for the implementation of an individual approach to each student. That is, it is important for teachers to take into account the properties of the cognitive and personal sphere, the creative potential of future specialists, as well as to carry out psychological support of the educational process. 
V.I. Vernadsky Taurida National University trains future specialists in the specialities of a classical university. In the process of learning our students have the opportunity to develop such qualities as flexibility, accuracy, originality of thinking, the ability to solve issues quickly and non-standardly, the ability to solve problematic issues and situations. Students have these opportunities both during professional classes and due to participation in the creativity training. This discipline is selective, but it gives the opportunity to develop the qualities necessary in life and work. During classes, students can determine their level of creativity, realize creativity in them and develop it, realize and overcome barriers that restrain creative potential. They can also form the skills and abilities to manage the creative process.

The main objective of the course is to update the creative abilities, creative personal potential of future specialists, to enhance the process of creating the personal and creative style of professional activity based on self-esteem, self-motivation and self-management.

The task of the course is the students' awareness of the creative nature of their own professional activities, understanding of their individual peculiarities, the level of development of personal abilities for managerial activities, other professionally significant qualities, mastering the mechanisms of creative self-realization in professional activities, strategies for the creative protection of the individual, ways of professional self-improvement, acquiring of knowledge and practical skills of organizing professional activities as a developing interaction aimed at enhancing the staff's creative activity.

It should be noted that in the process of personal development a larger role belongs to the teacher, who is able to direct students on the path of searching, to arouse a passion for searching in them. A teacher helps future specialists to enter the atmosphere of creativity, the circle of ideas, the work at which opens up broad opportunities for independent search. However, the problem of teaching creativity, preparation for professional creative activity is unusual - how to teach what you don't know, that is, something new, creative. The idea of a "free" upbringing, a "spontaneous" development of creativity originated from here. So, it is impossible to teach creativity directly in the usual sense of the word "teaching". In order to describe the processes of the formation of creative abilities, the concept of training impact is used. In this case, it is said about intellectual training. This is a system of flexible influences on the personality, aimed at the formation of abilities to creativity. 
The methods of searching for new solutions are divided into: group and individual. Among the group methods we should note "brain storming" of F. Osborne, the syectics of J. Gordon, creative discussion and the like. The socio-psychological aspect of organizing a creative group has a fundamental role in group methods of searching for new solutions. Among individual or combined methods we can mention the generalized heuristic method by O. M. Polovinkin, the method of association garlands, or metaphors, the "method of the sevenfold search" by G. Ya. Bush and the method of "morphological analysis" by F. Zwickey.

In our opinion, the awareness of a person of his or her potential, the prospect of personal and professional growth encourages a person to constant experimentation, that is, to creativity.

The educational training of these specialists should contribute to the development of individuality, the formation of the personality, the upbringing of socially active citizens capable of conscious life choices, as well as meeting the needs of society and the state for highly qualified specialists who would be able to enrich the intellectual, cultural potential of the Ukrainian people with their knowledge, skills, and moral qualities.

Creative training systems, as a rule, contain a combination of many methods, but they are not focused on a specific result, but on an impetus to creativity. At the classes dedicated to the development of creativity, it is necessary, first of all, to create a free gaming atmosphere aimed at ensuring the comfort of communication, confidence in one's strengths, one's own and group members' creative potentials.

In our opinion, the awareness of a person of their potential, the prospect of personal and professional growth encourages him to constant experimentation, that is, creativity.

In creativity, both social and personal factors, in particular the psychological qualities of a person, his or her character, willpower, ingenuity, passion, experience, intelligence, intuition, imagination, and so on, take on special significance. An important condition for creativity is the perception of new ideas, the ability to find and raise problems, the independence of behaviour and judgment and at the same time the ability to give in and abandon their previous thoughts, criticality, courage, and tolerance. Perseverance, insistence, the ability to ensure the regularity and rhythm of mental work are usually considered an important subjective condition of creativity.

The resultative character of creative thought does not depend not only on consciousness, but also on unconscious ideas, impulsive guesses, 
which perform the function of impulse regarding valuable associations. These factors of creativity give rise to a variety of theoretical ideas about the creative process.

Consequently, the task of the teacher is to actively include each student in practical types of creative activity at higher educational establishment, to create conditions for creative freedom in choosing the type of activity, sources, and the embodiment of their findings. Summarizing the abovementioned, it can be affirmed that the modern unstable, crisis state as a transitional period of the society development, including in the field of education, training of specialists, requires the active involvement of the main principles of humanization, individualization in the interaction process of the holistic educational system.

However, in our opinion, the development of creative abilities requires a long-term influence and should be the subject of attention of teachers from the first days of the students' training. In our opinion, it is necessary to pay attention to rearing of hankering for creativity at all the stages of training.

\section{CONCLUSIONS}

Thus, the general concept of training future specialists has a humanistic orientation, fundamental, scientific, general cultural, practical content of students' education, taking into account their individual characteristics and potentials. That is, it is necessary to create conditions for the implementation of an individual approach to each student, to take into account the properties of their cognitive and personal sphere, creative potential.

The educational training of these specialists should contribute to the development of individuality, the formation of the personality, the upbringing of socially active citizens capable of conscious life choices, as well as meeting the needs of society and the state for highly qualified specialists who would be able to enrich the intellectual, cultural potential of the Ukrainian people with their knowledge, skills, and moral qualities.

Psychological and pedagogical conditions conducive to the development of creative thinking consist of the teacher's choice of the forms, methods, means of education, as well as the items that are offered by the educational institution. An important factor is the organization of the educational process, when students' initiative is stimulated, confidence in their strengths and capabilities is formed in them, independence is supported and imagination is developed. That is, training 
activity contributes to the development of a personality with such inclinations that would meet the requirements of modern society - that is, specialists who possess a high level of intelligence, knowledge, skills, and who would be able to solve applied problems successfully. Only individuals whose creative thinking is developed can satisfy such requirements. So, taking into account the requirements of the labour market, it can be concluded that there is an objective need for training polyfunctional specialists.

\section{SUMMARY}

The article reveals the complex process of developing a student's creative personality. The most significant factors influencing the development of creative thinking of an individual when studying at a higher educational establishment have been considered and analysed. The main factors of stimulating the development of creative abilities have been determined on the basis of the personality-oriented nature of the teacher's interaction with students, the use of psychological and pedagogical technologies that ensure students' independent activity in the process of creative work and the systematic nature of academic work with students in a creatively developing environment. It has been found out that creative abilities develop in the conditions which stimulate this process.

It is said about the creativity training, which is held at V.I. Vernadsky Taurida National University. The areas for the student's development as an individual have been provided. The importance of developing the young professionals' creativity in modern Ukraine has also been emphasized.

\section{REFERENCES}

1. Андреев B.A. Диалектика воспитания и самовоспитания творческой личности. - Казань, 1998.

2. Дзвінчук Д. Формування позитивної мотивації студентів при вивченні гуманітарних дисциплін в технічному університеті // Проблеми викладання гуманітарних дисциплін у технічних навчальних закладах. Матеріали регіональної науково-методичної конференції. - Івано-Франківськ, 2001. - С. 5-8.

3.Здібності, творчість, обдарованість: теорія, методика, результати досліджень: Колективна монографія / За ред. В. Моляко, О. Музики. - Житомир: Рута, 2006. - 320 с. 
4. Зязюн Л. Академічні виховні цінності в системі освіти Франції // Вища освіта України. - 2005. - № 1. - С. 110-116.

5. Иванова И. П. Развитие творческого мышления студентов в условиях проблемнодеятельностного обучения / И. П. Иванова. Ставрополь, 2002.

6. Кривопишина О.А. Психологія творчості [Текст] / О.А. Кривопишина. - Суми: СумДУ, 2009. - 81 с.

7. Кучерявий I.T. Творчість - основа розвитку потенційних джерел особистості: Навч. посібник. - К., 2000.

8. Лушин П.В. Два виміри принципу «не нашкодь» і кодекс екологічності / П.В.Лушин / / Практична психологія в системі вищої школи: монографія / за ред. Т.В. Бушуєвої, С.О. Ставіцької // Авт. кол. кафедри практичної психології та психотерапії. - К.: НПУ імені М.П. Драгоманова, 2012. с. 38-53.

9. Малімон B.I. Перспективи формування та розвитку студента як творчої особистості / В.I. Малімон // Вища освіта України. 2006. - № 1. - C. 142-145.

10. Мерлин В. Очерк интегрального исследования индивидуальности. - М., 1986. - 256 с.

11. Моляко В.О. Психологічні проблеми творчої діяльності та обдарованості дітей і молоді Наук. записки Інституту психології ім. Г.С. Костюка АПН України Вип. 19: Актуальні поблеми психології. - К., 1999.

12. Моляко В.О. Психологічні проблеми творчої діяльності та обдарованості дітей і молоді Наук. записки Інституту психології ім. Г.С. Костюка АПН України Вип. 19: Актуальні поблеми психології. - К., 1999.

13. Рубинштейн С.Л. Проблемы общей психологии. - М., 1973.

14. Сисоєва С.О. Основи педагогічної творчості вчителя: Навч. посібник. - К., 1994.

15. Фромм Э. Иметь или быть. 2 изд., доп. - М.: Прогресс, 1990. - $180 \mathrm{c}$.

\section{Information about the author: Vynohradova V. Ye.}

Dr (PhD), Associate Professor, Head at the Psychology and Pedagogy Department of the V. I. Vernadsky Taurida National University 33, I. Kudry str., Kyiv, Ukraine 